\title{
Regrettable Indifference
}

\author{
By GREGORY CLARK
}

If a gyrfalcon were to appear, in white majesty striking the air on its lithe pointed wings above the crowded five o'clock streets amid the skyscrapers of one of our biggest, livest, most intelligent cities, how many of the thousand hastening home-goers would so much as look up at it? Even if someone who knew were to shout and point skyward to it, how many would pause for one glance, let alone a second glance? IJot a dozen, not a score, certainly not a hundred.

The number of people interested in the natural world around us-in the creatures which share with us the mystery and the miracle of life -has always been small. It is a shock to those attracted to wild nature to discover that backwoodsman and guides to whom they look for a wealth of wisdom in this field are little interested in any living thing other than the muskrat, beaver and raccoon they might trap, the deer they might eat, and the two or three species of fish off which they might make a living. Indeed, with regard to nearly all the rest of the wilderness creatures they are usually as filled with myth and nonsense as a cave dweller from the downtown of cities.
On the farm and in villages which wild nature literally hems in, the interest in birds and animals, trees and plants is, with exceptions as rare as are bird watchers in cities, purely perfunctory and ill-informed. Not every farmer knows that as a rule seven or more species of wild sparrow pass across or live in his fields; that as high as twenty species of warblers, all as distinct from one another as emeralds are from rubies, move through his woodlot in spring and autumn; or that probably six species of hawks are as familiar with his fields and fence rows as he is. To him, they are chicken hawks. That's all, Chicken hawks.

Well, I don't promise you a gyrfalcon rowing on pinions, not wings, across the skyscrapered downtown. I have lived sixty-three years without seeing one; and I have looked for fifty years. But I might suggest that at this time of year, the great hawk migrations are taking place across many aisles of Canada, and you might, if you are lucky, see one of the "kettles", as they are called, kettles of hawks numbering hundreds, riding the thermals from the September earth, high in the clouds, and moving in majestic slow spirals, south, south, south.

- "The Packsack" Regina Leader Post

\section{Saskatoon Natural History Society}

The organization meeting of the Saskatoon Natural History Society was held in the Physics Theatre, University of Saskatchewan, on Friday evening, October 14th, with 75 people in attendance.

A committee was named to nominate a slate of officers, and recommend such things as membership fees, meeting nights, and aims and objects of the society. These nominations and recommendations will then be presented to the next meet- ing of the Society in November. This provisional committee consists of Dr. Ronald M. Bremmer, chairman; J. Frank Roy; Dr. D. S. Rawson; S. Mendis; Dr. L. G. Saunders; W. Hyshka, and Dr. Stuart Houston.

The evening program consisted of a talk by Dr. Stuart Houston, entitled "Rambles of a Bird Bander" and illustrated with 160 kodachrome slides of Saskatchewan scenes and wild life. 